\title{
BAJRONICZNA KREACJA SZATANA W WYBRANYCH UTWORACH „ANIELSKIEJ SAGI” MAI LIDII KOSSAKOWSKIEJ
}

\section{The Byronic Creation of Satan in Selected Works of „Angelic Saga” by Maja Lidia Kossakowska}

Keywords: Lucifer, satan, Angelic Saga, Kossakowska, Byronic hero

Contact: Uniwersytet Śląskiw Katowicach; kon.k.ziel@gmail.com

W dobie romantyzmu, w czasach gdy stare wzorce okazywały się niewystarczające wobec oczekiwań, artyści coraz śmielej sięgali w stronę tego, co do tej pory uznawane bywało za niegodne naśladowania i nazywania. Szeroko pojęte zło, od wieków kuszące i intrygujące człowieka, wreszcie znalazło sobie mediatorów, próbujących zredefiniować otaczający ich świat. Sfera sacrum przestawała być krystalicznie czysta. Bóg, jako istota wszechmocna, niejednokrotnie okazywał się być tyranem, a szatan stawał się coraz bardziej podobny człowiekowi.

To właśnie w jego postaci, tak różnej od średniowiecznych przedstawień, dostrzegano całą istotę postawy romantycznej. Z okrutnej, cuchnącej siarką poczwary, władca piekieł zmienił się we współczującego, targanego wichrami uczuć, mrocznego anioła. Anioła, w którego upadku dostrzegano przepotężną siłę, potrzebną by powiedzieć „nie” wobec zła i niesprawiedliwości płynących z boskich praw. Największego indywidualistę, pierwszego, który ośmielił się podnieść głowę i walczyć w imieniu własnej sprawy, nawet wtedy, gdy walka ta z góry skazana była na porażkę. Taka kreacja oraz prezentowana przez nią postawa z chęcią wykorzystywana była przez licznych pisarzy i poetów, idealnie wpasowując się w oczekiwania ówczesnych twórców i odbiorców. Mimo upływu lat i literackich (potrzeb) pokoleń czytelników, szatana w takiej postaci odnaleźć możemy także w różnorakich dziełach współczesnych. Jednymi z nich są wchodzące w skład Cyklu Anielskiego, powieści Mai Lidii Kossakowskiej, polskiej autorki fantasy.

Za pierwszego upadłego a zarazem władcę piekła, obiera ona Lucyfera, byłego archanioła, jednego z członków spisku przeciw eonom. $\mathrm{Na}$ początku powieści 
przedstawiony zostaje jako zdecydowany, pewny swoich przekonań, wierny sługa Pana. Nie wyobraża sobie możliwości wystąpienia przeciwko Bogu: „W żadnym wypadku! zawołał Lucyfer, wyraźnie poruszony. - Przeciw Panu?! Nigdy! To nie wchodzi w grę!" (Kossakowska 2014: 24). To właśnie on, jakoby przypadkiem, namówiony przez Samaela zostaje przywódcą powstania, które kończy się wygnaniem. Należy zauważyć, że wizerunek Lucyfera (tytułowanego także „Niosącym światło” lub „Gwiazdą zaranną") jako pierwszego buntownika i władcy piekła utrwalił się w kulturze popularnej. W Siewcy Wiatru pojawia się tak, jak widzieć go mogli romantycy - jako tego, który za swój śmiały krok potępiony został przez Boga: „Chcieliśmy zwrócić Jego uwagę, zaprotestować, wymusić jakąś reakcję. Nie spodziewaliśmy się, że spuści nas na zbity pysk. (...) Wiesz, jaki to był dla nas szok? Garstka szczeniaków, która nagle ma dowodzić potężnym buntem" (Kossakowska 2014: 483-484).

Stał się bohaterem, który cierpi przez swoje czyny, jednak jest w stanie przyjąć daną mu rolę, tak bardzo różną od jego pierwotnej postawy. Nie potrafi wyzbyć się swych pozytywnych, ,anielskich” cech. Okrucieństwo napawa go obrzydzeniem, nie jest w stanie do końca zaakceptować reguł panujących w głębi. U władzy trzyma się dzięki pomocy jedynego prawdziwego przyjaciela - Asmodeusza. Warto zwrócić uwagę na jego wygląd, który dużo bliższy jest wizji romantycznej. Nie jest to średniowieczny, odrażający diabeł. Diabeł taki, jakim widzieć go mógł Torquato Tasso, pisząc Jerozolime Wyzwolona:

Wszytek był czarny od głowy do pięty,

Kosmate piersi gęsta broda kryła,

Miąższy u gęby wąs wisiał pomięty,

W czele miał ieden, we łbie rogów siła,

A ukrwawiona gęba była taka,

Iako głęboka straszna przepaść iaka.

Iako Mongibel zaraźliwe pary

Y smród wypuszcza, tak y iemu z gęby

Śmierdziało właśnie, a z nosa bez miary

Puszczał, aż brzydko, plugawe otręby (Tasso 2020: 2187-2198).

Literaturoznawca, Stefan Munch, pisze o tym następująco w rozprawie Uśmiech anioła: „Przez długi czas malarskie wizualizacje szatana eksponowały przede wszystkim jego nieopisaną brzydotę. Zastępy diabelskie, dręczące grzeszników w niezliczonych przedstawieniach Sądu Ostatecznego (...) były pod każdym względem 
odrażające" (Münch 2012: 58). Polski badacz ukazuje także inne spojrzenie na upadłego Lucyfera: „Jednakże Szatan Marina jest smutny, ponieważ czuje się przede wszystkim upadłym aniołem, già di luce Angel più bello (niegdyś najpiękniejszym aniołem światła) oraz la prima stella del matutino Ciel (pierwszą gwiazdą porannego nieba). Na obrazie Lorenza Lotto Archaniot Michat stracający Lucyfera (ok. 1550) oglądamy szatana jako istotę piękną" (Münch 2012: 58). Lucyfer jest upadlym aniołem; anielskie piękno, pomimo piętna upadku nadal jest w nim dostrzegalne. Łaskawym okiem na postać Lucyfera spojrzeli przede wszystkim romantycy. Właśnie taką kreację odnaleźć możemy w Kainie Byrona, na co uwagę zwraca Maria Janion:

W tym momencie, oczywiście, pojawia się Lucyfer - piękny („,nie tak piękny jednak, jak był i mógł być”, tak go widzi Kain) i silny, ma „,smętne oblicze duchów myślących". Jest prawie już tak piękny jak później u Lautrémonta („Twarz bardziej niż ludzka, smutna jak wszechświat, piękna jak samobójstwo”) czy u Baudelaire’a („Znalazłem definicję Piękna, mojego Piękna. Nie utrzymuję bynajmniej, że Radość stanowi jedną z jego ozdób najbardziej prostackich, podczas gdy Melancholia jest dla niego, by tak powiedzieć, znakomitą towarzyszką, do tego stopnia, że nie pojmuję wprost typu Piękna, w którym mieściłoby się Nieszczęście. Można pojąć, że - wspartemu, inni powiedzieliby: nawiedzonemu przez te idee - trudno byłoby nie wysnuć wniosku, że najdoskonalszym typem Piękności męskiej jest Szatan - w rodzaju miltonowskiego") (Janion 1972: 210).

Rysuje się tutaj kolejna cecha romantycznego Lucyfera, na którą zwraca uwagę także polska badaczka: „«Piękno przeklęte jest stałym atrybutem Szatana; zniknęły grzmoty i smród jak z Mongibell, ślady po ponurym średniowiecznym demonie» konkluduje Praz na podstawie Miltona" (Janion 1972: 212). Podobny, posągowo piękny Lucyfer, zostaje stworzony przez Kossakowską: „Czerwony poblask płomieni obrysowujący sylwetkę Władcy Głębi, prześlizgujący się po krótko przystrzyżonych włosach barwy piasku, przydawał Lucyferowi podobieństwa do granitowej rzeźby. Wrażenie potęgowały chłodne, szare oczy" (Kossakowska 2014: 150). Oczy stają się jednym z najistotniejszych cech wyglądu romantycznego wizerunku Lucyfera. To one ukazują jego prawdziwe oblicze, stają się zwierciadłem, przez które na świat spogląda dusza jej właściciela. Dostrzega to Praz, o czym następująco pisze Janion: „Praz zwraca uwagę zwłaszcza na oczy miltonowskiego Szatana - posępne, świadczące o ogromnym smutku i strachu, zmieszanym $\mathrm{z}$ upartą dumą i twardą nienawiścią - na oczy największego z buntowników, oczy niezapomniane, przejmujące oczy, którymi romantycy i surrealiści spojrzeli na świat (Janion 1972: 212). 
Mimo całego piękna, na obliczu szatana widać skutki upadku: „«jego twarz poorana była głębokimi bliznami od piorunów, a na jego bladych licach malowała się troska, lecz spod brwi patrzyła nieugięta odwaga i rozumna duma, czekając zemsty... »" (Janion 1972: 212). Oraz, analogicznie, u Kossakowskiej: „Pojawiła się na ich miejsce inna twarz. Pogrążonego w rozpaczy, zdruzgotanego potępieńca, który nie miał już po co żyć. Maska, w jaką zmieniło się po klęsce oblicze Lucyfera" (Kossakowska 2014: 63).

Problematyczne może okazać się utożsamianie Lucyfera z szatanem. Lucyfer stał się aniołem upadłym na skutek źle przetłumaczonego fragmentu, pochodzącej ze Starego Testamentu, Księgi Izajasza, na co wskazuje pisarz i poeta, Gustav Davidson, który w książce Słownik aniołów, w tym aniołów upadtych, pisał następująco: „Jakożeś spadł z nieba Lucyferze, któryś rano wschodził. (...) Apostrofa ta w rzeczywistości skierowana jest do Nabuchodonozora, króla Babilonu" (Davidson 1998: 189). „Przypadkowość” tego upadku dostrzega także autorka Siewcy Wiatru i wykorzystuje przy kreowaniu wizerunku swojego władcy Głębi. Lucyfer staje się więc buntownikiem z przypadku, a nie z własnej woli. Jednego z najwierniejszych i oddanych aniołów do zdrady skusić mógł tylko prawdziwy szatan - powieściowy Samael. Anioł światłości, Gwiazda Zaranna, okazuje się silniejszy niżby wszyscy przypuszczali. Zmuszony do przywdziania maski, nieprzerwanie odgrywa rolę narzuconą mu przez los. Nie poddaje się, ani nie okazuje słabości. Przez tysiąclecia przymusowego panowania nad piekłem dojrzewa; odkrywa swoją prawdziwą naturę. Patrząc wstecz, na całą przebytą drogę, dostrzega zmianę, która w nim zaszła. Z potulnego, wielbiącego Boga anioła, poprzez wmieszaną w bunt ofiarę spisku, staje się wreszcie godnym swego miana imperatorem. Przemianę tę ukazuje Kossakowska w monologu Lucyfera w drugim tomie Zbieracza Burz:

Sam chciałeś być jak on. Młody, niezależny, po wręby wypełniony rebelią przeciw wszystkiemu i wszystkim. Własnemu krajowi, własnej pozycji, własnym decyzjom. Tyle że jesteś byłym archaniołem, Lucyferem, Niosącym Światło. Przywódcą największej rebelii w dziejach wszechświata. I nie masz co udawać młodzieńczych rewolucji. Nie przystoi ci ta śmieszna maska. Romantyka i marzyciela. (...) Biednego lojalnego Rycerza Miecza niegdyś perfidnie wrobionego przez Samaela w przywództwo wojskowego puczu. Łagodnego Lampki, który żałuje, że przeciwstawił się Jasności. Bo nie żałujesz. Nie. Mowy nie ma. I jesteś cesarzem Otchłani, wodzem, który bierze odpowiedzialność za własne czyny. Imperatorem piekieł (Kossakowska 2013: 75).

Dopiero wtedy, akceptując swoją rolę, jest w stanie z premedytacją przedsięwziąć 
kolejny krok. Następny, tym razem w pełni świadomy bunt przeciw okrutnemu Bogu. W tym momencie dopełnia się jego przemiana, w pełni pojmuje rolę, którą odegrał w przeszłości i którą odegrać mu przyjdzie jeszcze w przyszłości: „Już raz podjął wyzwanie, nie dał się stłamsić, oznajmił Światłości i światu swoje zdanie. Nie ustąpił. A za nim poszły rzesze innych. Teraz też tak się stanie. Cokolwiek oznacza ten absurdalny kaprys wyższych mocy, on, Lucyfer, nie zgadza się na to. Nie chce być bezwolną marionetką w rękach jakiejkolwiek potęgi, czy to jasnej, czy ciemnej” (Kossakowska 2013: 61).

On, pierwszy buntownik, gotowy jest do kolejnej, nierównej walki z silniejszym od siebie przeciwnikiem. Mimo uprzedniej porażki, mając świadomość, że zapewne i teraz czeka go klęska, zdecydowany jest sprzeciwić się boskiemu poleceniu rozkazowi zniszczenia ziemi. On - szatan, władca piekieł, nie godzi się z taką niesprawiedliwością. Paradoksalnie to właśnie on gotowy jest stanąć w obronie ludzkości. W rozmowie z Asmodeuszem Lucyfer wyjaśnia przyczynę swojej decyzji:

Głębia zrodziła się z buntu. Z niezgody na niesprawiedliwość. Z odwagi śmiałego wystąpienia przeciw potężnemu autorytetowi. Najpotężniejszemu w Kosmosie. Stwórcy. Bo działo się zło. Bo nie było, cholera, sprawiedliwości! Ja i wszyscy, którzy wtedy za mną poszli, rzuciliśmy wyzwanie Światłu. Nie pochyliliśmy pokornie karków, nie zaufaliśmy ślepo. Umieliśmy podnieść dumnie głowy i krzyknąć: „Nie!”. A ty myślisz, że co? Że teraz się przestraszę? Że pozwolę, aby stało się to bezsensowne, niewyobrażalne zło? Hekatomba na skalę wszechświata? Że ze strachu dopuszczę, aby ktoś większy i silniejszy ode mnie, wszystko jedno, Pan czy Cień, realizował bezkarnie swoje mordercze kaprysy? Sądziłeś, że dopuszczę do zniszczenia Ziemi?! Życia? Czy ty sobie zdajesz sprawę, ile tam jest życia, Mod? Naprawdę choć przez chwilę przypuszczałeś, że pokornie położę uszy po sobie i odsunę się na bok? Chyba mnie nie znasz, przyjacielu. Nie znasz mnie (Kossakowska 2013: 74).

Podobny opis Lucyfera odnaleźć możemy u Byrona. Jego szatan również staje do samotnej walki z okrutnymi, boskimi prawami, ustanowionymi przez Kreatora, a zarazem destruktora:

LUCYPER

O to zapytaj niszczyciela.

KAIN

Kogo?

LUCYPER 
Stwórcy. On po to tworzy, aby niszczył.

(...)

On jest zwycięzcą, ale nie jest wyższym!

On ma hołd wszystkich, lecz nie ma mojego.

Wiodę z nim ciągłą walkę, jako wiodłem

W najwyższym niebie. Wśród wieczności, wpośród

Niezgruntowanych Hadesu parowów,

Wśród bezmierności nieskończonych czasów

Staczam z nim walkę! (Byron 2010:11).

Bóg, którego prawdziwą postać za pośrednictwem Lucyfera poznaje Kain, okazuje się mordercą i niszczycielem. Zarówno daje życie, jak i je odbiera. Szatan natomiast, podobnie jak później u Kossakowskiej, lituje się nad nieświadomym zagrożenia człowiekiem i zostaje jego cichym sprzymierzeńcem - obrońcą i nauczycielem. Jednak zarówno u Byrona jak i u Kossakowskiej sprawa ludzka wydaje się być tylko kolejnym pretekstem do walki w imieniu wyznawanych ideałów. Istotą Lucyfera staje się samotny bunt. Okazuje się on jednostką odosobnioną, stającą naprzeciw obowiązujących norm. Jego bezpośrednie, śmiałe wystąpienie podrywa zastępy do działania. I takiego właśnie widzimy go w kontynuacji Siewcy Wiatru, powieści Zbieracz Burz:

Zostajesz sam. Jak zwykle. Król buntowników i jego wesołe państwo.

Lucyfer, Niosący Światło. Największy rewolucjonista w dziejach.

$(\ldots)$

Na razie jesteś sam.

W pustej, cichej komnacie.

Bardzo cichej i bardzo pustej (Kossakowska 2013: 77).

Decyzja, nie ważne jak bardzo dramatyczna, zawsze podjęta zostaje w samotności. A płynącym z jej podjęcia cierpieniem Lucyfer zostaje obarczony w pełni świadomie. Janion zwraca uwagę na niesamowitą, ludzką stronę upadłego anioła.

Lucyfer jest tym, który poznał do końca dolę człowieka (...). Poznał kondycję ludzką jako upadły anioł, jako ten, który przeszedł przez klęskę, przez cierpienie, ale przede wszystkim jako ten, którym szarpały furie buntu - uległ im i nie żałuje tego, bo zyskał poznanie i stał się ,,smutnym śmiertelnie" towarzyszem i sojusznikiem człowieka. Powód 
romantycznych sympatii dla Szatana - pokonanego, cierpiącego, prześladowanego, wzniosłego w swej wytrwałości, a więc prometejskiego, wyjawił pięknie Shelley: Nic nie jest w stanie przewyższyć energii i wspaniałości charakteru Szatana przedstawionego w Raju utraconym. (...) Na płaszczyźnie moralnej Szatan Miltona tak samo przewyższa swego Boga, jak ktoś kto mimo przeciwieństw i męczarni trwa przy doskonałym w swym pojęciu zamiarze, przewyższa tego, kto z zimną pewnością niechybnego zwycięstwa wywiera na wrogu najstraszniejszą zemstę (...) mając wyraźnie na celu rozdrażnienie go tak, aby zasłużył sobie na nowe tortury (Janion 1972: 214).

W wykreowanej przez polską autorkę postaci Lucyfera z łatwością dostrzec możemy romantyczne wzorce, którymi przed laty szatan „obarczony” został przez Byrona oraz rzeszę autorów - pisarzy i poetów, we władcy piekieł dostrzegających kogoś więcej niż wcielenie całego zła obecnego w świecie. Pierwszy buntownik stał się wzorcem; krzewicielem prometejskiej idei. Stał się bliski człowiekowi, jako istota najbardziej doświadczona przez okrutne prawa, przeciw którym sprzeciwiła się, sprowadzając na siebie klęskę. Klęskę, która otwarła drogę dla nadziei i możliwości walki.

\section{Summary}

The article shows that Lucifer, as a byronic hero, appears in contemporary fantasy literature. Kossakowska refers to the Romantic tradition. It depicts Satan as a beautiful man with the mark of falling. His appearance and disability is a consequence of disobedience to God. Lucifer rebels against divine injustice. He defends humankind and presents himself as his savior. Lucifer in Kosskowska's work is the "first rebel" who, despite losing the case, is ready to fight. He has the characteristics of a byronic hero: he is an individualist and rebel who suffers because of his past deed. Kossakowska's hero accepts the responsibility for his actions, consistently fulfilling the role imposed on him.

\section{Literatura}

Byron, G. G. Kain (PDF). Tłum. Kasprowicz, J., Paszkowski, J. Poznań: Imprint, 2010.

Davidson, G. Słownik aniołów, w tym aniołów upadłych. Tłum. Ruszkowski, J. Poznań: Zysk i S-ka, 1998.

Kaczor, K. Anioły wcale nieanielskie. Mieszkańcy niebios Mai Lidii Kossakowskiej. In: Ługowska, J. (ed.) Anioł w literaturze $i$ w kulturze. Tom 2. Wrocław: Atut, 
2005.

Kossakowska, M. L. Siewca Wiatru. Lublin: Fabryka Słów, 2014.

Kossakowska, M. L. Zbieracz Burz (PDF). Tom 1. Lublin: Fabryka Słów, 2013.

Kossakowska, M. L. Zbieracz Burz (PDF). Tom 2. Lublin: Fabryka Słów, 2013.

Mazurkiewicz, A. Degradacja figury anioła we współczesnej kulturze popularnej (na przykładzie literatury fantasy). In: Ługowska, J. (ed.) Anioł $w$ literaturze iw kulturze. Tom 2. Wrocław: Atut, 2005.

Milton, J. Raj utracony. Tłum. Słomczyński, M. Kraków: Zielona Sowa, 2011.

Münch, S. Uśmiech anioła. Pogranicza muzyki, malarstwa i literatury. Lublin: Wydawnictwo UMCS, 2012.

Janion, M. Kain i Lucyfer. In: Janion, M. (ed.) Romantyzm, rewolucja, marksizm. Warszawa: Wydawnictwo Morskie, 1972.

Tasso, T. Jerozolima wyzwolona (online). Tłum. Kochanowski, P. Dostęp z: https://wolnelektury.pl/katalog/lektura/tasso-jeruzalem-wyzwolona.html (202002-03). 